Agro-Science Journal of Tropical Agriculture, Food, Environment and Extension Volume 20 Number 4 (Special Issue, October 2021) pp. 52 - 58

ISSN 1119-7455

\title{
PATTERNS FOR COST-SHARING OF AGRICULTURAL TECHNOLOGY TRANSFER IN NIGERIA
}

\author{
${ }^{* 1}$ Ozor N., ${ }^{2}$ Madukwe M.C., ${ }^{3}$ Garforth C., ${ }^{1}$ Agwu A.E. and ${ }^{4}$ Chukwuone N.A. \\ ${ }^{1}$ African Technology Policy Studies Network (ATPS) \\ 8th Floor, The Chancery, Valley Road, P.O. Box 10081-00100, Nairobi, Kenya \\ ${ }^{2}$ Department of Agricultural Extension, University of Nigeria, Nsukka, Enugu State, Nigeria \\ ${ }^{3}$ Department of International \& Rural Development, School of Agriculture, Policy \& Development, \\ Faculty of Life Sciences, The University of Reading, RG6 6AR, United Kingdom \\ ${ }^{4}$ Center for Rural Development \& Cooperatives, University of Nigeria Nsukka, Enugu State, Nigeria \\ *Corresponding email: nozor@atpsnet.org, sunny_ozor@yahoo.com; Phone: +254 (0) 713161928
}

\begin{abstract}
With recent changes in the financing and delivery of agricultural technology transfer worldwide due to inability of many governments to cope with varied needs of clients, most reforms currently being initiated by governments tend towards a pluralistic approach and financial participation of all stakeholders. One of such reforms is through cost-sharing. The authors examined stakeholders' (extension professionals and farmers) opinions on the appropriate patterns for cost-sharing of agricultural technology transfer in Nigeria. The study was carried out in six geopolitical zones of Nigeria. Multistage random sampling technique was applied in the selection of 268 farmers and 272 extension professionals. Mean scores and t-test statistics were utilized in realizing the objectives of the study. Results show that the stakeholders' overall opinion on the appropriate pattern for cost-sharing was for beneficiaries of service to pay specified amounts of money to extension organizations every farming season through their cooperative societies. Results further showed that farmers proved to have more ideas on the best patterns of sharing the cost of technology transfer than the extension professionals. It was concluded that for cost-sharing to be effective, all the stakeholders have to participate in decision-making and implementation processes of agricultural technology transfer in the country.
\end{abstract}

Key words: cost-sharing, agricultural technology transfer, farmers, extension professionals, Nigeria

\section{INTRODUCTION}

Participation of client farmers in the financing of agricultural technology transfer is rapidly becoming a paradigm in discussions of rural development policy, and consequently a variety of attempts to put this concept into practice are underway (Katz, 2002). In the public extension sector, the capacities of human resource management are deficient and this impedes the delivery of an effective, good quality service to farmers (Kelly et al., 2012). Many development thinkers believe that the benefits accruing from extension services are private and therefore should be funded by such private interests. Others too believe that the quality of service delivered by the public extension personnel is poor and too general to meet individual farmers' interests otherwise referred to as supply driven. It is top-down oriented and more so marginalizes some expected beneficiaries. Unfortunately, also, cutbacks in national budgets and the withdrawal of international financial donors such as the World Bank have made it extremely difficult for some developing country governments to sustain agricultural technology transfer that can provide efficient and effective service. Dissatisfaction with effectiveness and efficiency of services as well as financial constraints of governments, and a reconsideration of the role of governments in general, have led to a discussion on alternative approaches to financing extension (Katz, 2002).

Cost-sharing, which is a system where beneficiaries of services pay user fees has been one of the probable options recommended by extension experts and practitioners in order to achieve success in sustaining agricultural extension service or agricultural technology transfer (used interchangeably in this paper) in many countries. This system adopts the mix of public- private sector participation in financing agricultural extension. There is no fixed rule as to the percentage of contribution that must come from each stakeholder as this is determined by individual country circumstances, the prevailing socioeconomic environments, nature of agricultural production, and a host of other factors. It is therefore left for any country which hopes to adopt this approach to conduct a situational analysis and feasibility study prior to its introduction. 
Already, in some developed and developing countries, farmers now pay for some costs of technology transfer service. In France, threequarters of the operated extension budget is collected at the farm level through direct payments, contributions of agricultural organizations, and other direct and indirect taxes on agricultural inputs and products (Ameur, 1994). Several models of cost-sharing were also reported in Latin America and Nicaragua (Wilson, 1991; Keynan et al., 1997). For instance, women in a remote village of northern Viet Nam pay a public veterinarian for regular visits in their village to vaccinate piglets. They negotiated payment in kind where out of every six piglets raised to a marketable age, the women agreed to give one piglet to the veterinarian as remuneration (Katz, 2002). This formula greatly motivated the officers who ensured that as many piglets survived in as many households as possible. The case also shows that poor people in remote areas can, and are willing to pay for useful services, provided payment is in an appropriate form and pattern. Also, farmers in Kyrgyzstan paid the extensionist for assistance in the preparation of a business plan if it resulted in the approval of their loan application (Katz, 2002).

In Nigeria, however, the funding and delivery of agricultural technology transfer have rested mainly on the central government. The Agricultural Development Programme (ADP) established in 1975 is the agency officially mandated to carry out extension services and is based in each of the 36 states including the federal capital territory, Abuja. The ADP, in pursuance of its main objective of technology dissemination, adopts the training and visit $(\mathrm{T} \& \mathrm{~V})$ extension strategy. Thus, the ADP have operated the features of $T \& V$ extension strategy which included professionalism, single line of command, concentration of efforts, time bound operation, field and farmer orientation, regular and continuous staff training, and linkage with research.

Following the World Bank withdrawal of its funding support in 1995 to the ADPs and the lean contributions received from the federal and state governments, agricultural technology transfer suffered major setbacks. Farmers were not visited because extension workers were not paid their salaries and other incentives as and when due. Operational and service vehicles were grounded and could not be maintained. Many extension agents (EAs) turned their service motorcycles for commercial purposes in order to provide meals for their families. At the end, farmers did not receive agricultural information as required and this undoubtedly affected their production and income thereby undermining the goal of the agricultural development programmes. These negative effects were as a result of poor funding status of the public extension agency by the government. The government, on the other hand, claims that many of its public enterprises gulped billions of Naira without yielding much positive results in terms of customers' satisfaction and returns on investments (National Council on Privatization, NCP, 2001); hence, it embarked on the privatization and commercialization of these enterprises. The legal framework establishing cost-sharing in public services in Nigeria is the Public Enterprise Decree of 1999, which also established the privatization and commercialization ( $\mathrm{P} \& \mathrm{C}$ ) of public enterprises that commenced operation in the year 2000 .

There have been calls for private sector involvement in the provision of extension service in Nigeria as a result of government's dwindling development budgets and extremely poor progress in raising economic and social well-being of the populace through the public extension service (Omagbemi, 1998). The frustration with the inability of public extension services to reform themselves has led to radical proposals to "give" extension to the rural populace through participatory-oriented strategies (Kuitenbrower, 1981). Already, over $80 \%$ and $85 \%$ of farmers and extension professionals respectively are favourably disposed to cost-sharing of agricultural technology transfer in Nigeria (Ozor et al., 2007). It has also been shown that farmers pay for services of private veterinarians and para-veterinarians in animal production in Nigeria (Igbokwe, 2001).

However, the critical question to ask is: what pattern(s) of payment or financial participation could be adopted to ensure effective cost-sharing of agricultural technology transfer? What are the views of the stakeholders in extension delivery? And where do their views on the patterns of payment vary or conform? The researchers attempt to provide answers to these unassuming questions.

\section{Theoretical Consideration}

Traditional economic theory suggests that a free market in goods and services is the most efficient way of allocating resources and setting prices (Garforth, 2005). This is based on a situation where there are many willing buyers and many willing sellers, and information is freely available to all of them. The theoretical basis for this study was built around six market factors affecting farmers as noted by Garforth (2005), namely; (i) externalities, (ii) market power, (iii) information failures and risks, (iv) cost of establishing and enforcing agreements, (v) transaction costs, and (vi) whether the good or service is public or private.

The externality effect occurs where one's farming practice has a positive or negative effect on another farmer and such impacts are not paid for. This has been described as 'spillovers or third party effects' (Umali and Schwartz, 1994). A positive externality arises when the services provided (or consumed) by an individual, also benefits or spills over to others who have not paid for the service. A negative externality, on the other hand, arises when the services provided (or consumed) by an 
individual spills over and causes harm or injury to others. In both cases, the market does not provide the mechanism for collecting payment from the other people who benefited or compensation enforced on behalf of the injured parties (Pigou, 1932; Head, 1974). For example, in Nigeria, the droppings from a herd of cattle of the nomadic Fulani help to maintain the fertility of the soil on grazed lands. Services that prevent or cure contagious animal diseases have positive side effects for all people that keep animals in an area, because they reduce the risk that one's own animals contract the disease. On the other hand, the flaring of gas by an oil company into a community and its consequential effect on the ecosystem is an example of a negative externality.

Market power occurs where an entrepreneur usurps a monopoly condition in his/her environment to his/her advantage. An example is where a local businessman has a monopoly and can charge higher than market prices for agricultural inputs.

Information failures and risks occur where two people in a transaction have very different amounts of information on which to base their decisions (asymmetry); or where a sub-optimal outcome occurs because there is not enough information available to make a better decision (insufficient information). An example that is often cited is "adverse selection" where an insurance company unknowingly takes on a high risk client because it does not have the necessary information to screen out such clients. In an extension context, for example, users cannot judge the quality of an extension service at the time they receive it; its true value to the user may become apparent only later. This constitutes a risk to the user that may reduce the use of extension service that in fact would bring substantial benefits.

Transaction costs are the economic equivalent of friction in physical terms. Generally, some transactions are better suited to market-type arrangements, while others are better suited to hierarchical or ruledriven organizations (Bale and Dale, 1998). For example, contracting out is likely to be desirable where the supply of a good is contestable, quality and quantity can be easily measured and specified, and suppliers are numerous. On the other hand, when transactions occur frequently, are associated with uncertainty, and evolve specific assets of skills, hierarchical organization tends to be more efficient. However, where the supply of services is competitive, with reduced uncertainty, transaction costs are low. Therefore, evolving institutional framework that will make supply of services competitive will help lower transaction costs. Institutions that evolve to lower transaction costs are the key to the performance of economies (Meier, 1995). The cost of establishing and enforcing agreements which might include the legal cost of recovering a debt can be linked with transaction costs for such an economic production.
The public and private good information paradigm provides a well-defined structure, which allows one to derive clear propositions concerning, for instance, the design of contracts such as the cost-sharing arrangement (Meier, 1995). Information could be a public or private good based on economic principles of rivalry and excludability. The distinction between public and private goods is particularly important in differentiating goods and services that governments have an undisputed role to supply, due to market failure on the demand side (public goods), from those that government engage in due to market failure on the supply side (private goods). Therefore, because of the nature of information, cost-sharing arrangement should be made in such a way that fees are charged only for those information services that are private. Charging farmers some nominal sum for services can encourage them to exercise their right as information consumers and increase their voice in the management of technology generation and transfer, thereby ensuring program effectiveness. Farmers can choose who will provide the service, and agricultural extension providers who would want to remain relevant, must respond quickly to meet the farmers' information demands thus making the market competitive. In general, this will transmit to efficient technology delivery to farmers, increased output, and poverty reduction especially where the institutions and policy environment is safe and best patterns of participation are adopted.

\section{Purpose and Objectives}

The purpose of the study was to ascertain the opinions of farmers and agricultural extension professionals on the appropriate patterns for effective cost-sharing of agricultural technology transfer in Nigeria. The differences in opinion on these patterns among the stakeholders were also examined.

\section{METHODOLOGY}

The study was conducted in Nigeria which is made up of six geopolitical zones for administrative and agro-ecological purposes, namely; North West, North East, North Central, South West, South East and South South. The six zones were chosen for the study in order to obtain a feel of the various ethnic groups, tribes, regions, agro-ecological patterns, and administrative arrangements that were used in zoning the entire country. The population of the study comprised all farmers who were in contact with extension professionals (both contact and noncontact farmers) in the study area and the extension professionals themselves. A multi-stage random sampling technique was used to select the respondents. In the first stage, six states were randomly selected from the six geopolitical zones. They included Katsina (North West), Bauchi (North East), Kogi (North Central), Ondo (South West), Enugu (South East) and Rivers (South South). In the second stage, two agricultural zones 
were randomly selected from each state giving a total of 12 agricultural zones. From each of the selected agricultural zones, 25 farmers were randomly selected from a list of 100 farmers provided by extension personnel and opinion leaders in the zones for interviews. This gave a total of 300 farmers. Similarly, 26 extension professionals were randomly selected from each agricultural zone bringing the total to 312 . However, valid responses were obtained from 268 farmers and 272 extension professionals as shown in Table 1 .

Primary data were collected using a structured interview schedule and questionnaires for farmers and extension professionals respectively. These instruments were pre-tested for reliability using the split-halve correlation technique and validated by experts in the agricultural extension profession (the academia, extension administrators and rural development experts). The pre-test shows a reliability coefficient of 0.89 and was significant at 0.01 probability level. A reliability coefficient of 0.8 and above implies a satisfactory and an acceptable level of internal reliability (Bryman, 2004). Focus group discussions (FGD) were conducted in each zone to make the study more interactive and participatory oriented. Items discussed were centred on the specific objectives of the study and were equally used as a check and balance for the structured interview schedule and the questionnaire. Trained extension agents (EAs) assisted in the collection of data under the supervision of the researchers. This is to ensure that questions posed by the EAs conform to the validated instruments.

To ascertain the opinions of farmers and extension professionals on the appropriate patterns for cost-sharing, various proven patterns identified and or modified from literature, case studies and practical experiences were utilized. A four-point Likert type scale was developed and used against the identified patterns. The response options and values assigned were; most appropriate $=4$; appropriate $=3$; least appropriate $=2$; and not appropriate $=1$. Also, the mean of the scale, which is 2.5, was used as the cut-off point to determine the appropriateness of each pattern. Mean scores, standard deviations, and t-test statistics were used in realizing the objectives of the study. All significance was tested at 5\% level of probability.

Table 1: Distribution of respondent farmers and extension professionals answering questions on costsharing by geopolitical zones and states of origin, Nigeria

\begin{tabular}{llcc}
\hline $\begin{array}{l}\text { Geopolitical } \\
\text { zones }\end{array}$ & States & Farmers & $\begin{array}{c}\text { Extension } \\
\text { professionals }\end{array}$ \\
\hline Northwest & Katsina & 45 & 50 \\
Northeast & Bauchi & 50 & 40 \\
North central & Kogi & 50 & 45 \\
Southwest & Ondo & 42 & 52 \\
Southeast & Enugu & 40 & 45 \\
Southsouth & Rivers & 41 & 40 \\
Total & & 268 & 272 \\
Grand Total & & \multicolumn{2}{c}{540} \\
\hline
\end{tabular}

\section{RESULTS \\ Patterns for Cost-Sharing of Agricultural Technology Transfer}

The respondents' mean scores and standard deviations on the appropriate patterns for costsharing are presented in Table 2. Results show that the most appropriate pattern identified by both farmers and extension professionals was that beneficiaries of service should pay a specified amount to the extension organization every farming season through their cooperative societies $(\overline{\mathbf{x}}=$ 3.15: 3.10 respectively). Two other appropriate patterns identified by respondents (farmers and extension professionals respectively) were that the extension organization should determine the cost of technology transfer and charge a certain proportion of the cost on the recipient $(\overline{\mathbf{x}}=2.69: 2.93)$ and that beneficiaries should pay a specified amount monthly through their cooperative societies to the extension organization $(\overline{\mathbf{x}}=2.50: 2.77)$.

Nevertheless, farmers still considered beneficiaries paying a specified amount to the EAs incharge of their circle every farming season $(\overline{\mathbf{x}}=2.68)$ and payment of cost of technology transfer through community assembly every farming season $(\overline{\mathbf{x}}=2.62)$ as appropriate patterns for cost-sharing. The most inappropriate pattern identified by respondents was the payment of cost of technology transfer through the local council wards monthly $(\overline{\mathbf{x}}=1.84: 1.73)$.

\section{Differences in Respondents' Views on the Pattern for Cost-Sharing of Agricultural Technology Transfer}

The difference in opinions between farmers and extension professionals on the appropriate patterns for cost-sharing is presented in Table 3 . Results show that out of the nine patterns of cost-sharing investigated, the opinions of the respondents were statistically different in four. These included: the extension organization should determine the cost of technology transfer and charge a certain proportion of the cost on the recipient $(t=2.65)$, beneficiaries should pay a specified amount to the EA in-charge of their circle every farming season $(t=-4.90)$, beneficiaries should pay a specified amount to the extension organization monthly irrespective of technology disseminated $(t=-3.93)$, and beneficiaries should pay a specified amount monthly through their cooperative societies to the extension organization $(t=2.88)$.

Among these significant statements, the mean scores of farmers were higher than the professionals' mean scores in the following two statements; beneficiaries should pay a specified amount to the EA in-charge of their circle every farming season $(\overline{\mathbf{X}}=2.68: 2.22)$, and beneficiaries should pay a specified amount to the extension organization monthly irrespective of technology disseminated $(\overline{\mathbf{x}}=2.18: 1.84)$. Similarly, the mean scores of the professionals were higher than farmers' 
Table 2: Mean distribution of respondents' opinions on the possible patterns of cost-sharing, Nigeria $(n=540)$

\begin{tabular}{|c|c|c|c|c|c|c|c|}
\hline \multirow[b]{2}{*}{$\mathrm{S} / \mathrm{N}$} & \multirow{2}{*}{ Patterns } & \multicolumn{3}{|c|}{ Farmers } & \multicolumn{3}{|c|}{ Extension professionals } \\
\hline & & Mean & Std. Dev. & Rmk* & Mean & Std. Dev. & Rmk* \\
\hline 1. & $\begin{array}{l}\text { Beneficiaries should be paying a specified amount to the extension } \\
\text { organization every farming season through their cooperative societies }\end{array}$ & 3.15 & 1.01 & A & 3.10 & 0.93 & A \\
\hline 2. & $\begin{array}{l}\text { The extension organization should determine the cost of technology } \\
\text { transfer and charge a certain proportion of the cost on the recipient }\end{array}$ & 2.69 & 1.11 & A & 2.93 & 1.03 & A \\
\hline 3. & $\begin{array}{l}\text { Beneficiaries should be paying a specified amount to the extension } \\
\text { agents (EAs) in-charge of their circle every farming season }\end{array}$ & 2.68 & 1.11 & A & 2.22 & 1.09 & NA \\
\hline 4. & $\begin{array}{l}\text { Payment of cost of technology transfer through community assembly } \\
\text { every farming season }\end{array}$ & 2.62 & 1.24 & A & 2.08 & 1.01 & NA \\
\hline 5. & $\begin{array}{l}\text { Beneficiaries should be paying a specified amount monthly through } \\
\text { their cooperative societies to the extension organization. }\end{array}$ & 2.50 & 1.11 & A & 2.77 & 1.05 & A \\
\hline 6. & $\begin{array}{l}\text { Payment of cost of technology transfer through community assembly } \\
\text { monthly }\end{array}$ & 2.19 & 1.13 & NA & 2.08 & 1.01 & NA \\
\hline 7. & $\begin{array}{l}\text { Beneficiaries should be paying a specified amount to the extension } \\
\text { organization monthly irrespective of technology disseminated }\end{array}$ & 2.18 & 1.13 & NA & 1.84 & 0.92 & NA \\
\hline 8. & $\begin{array}{l}\text { Payment of cost of technology transfer through the local council } \\
\text { wards every farming season }\end{array}$ & 2.10 & 1.14 & NA & 1.94 & 0.99 & NA \\
\hline 9. & $\begin{array}{l}\text { Payment of cost of technology transfer through the local council } \\
\text { wards monthly }\end{array}$ & 1.84 & 1.05 & NA & 1.73 & 0.91 & NA \\
\hline & Cut off & 2.50 & & & & & \\
\hline
\end{tabular}

Table 3: Test of difference between farmers and extension professionals on the appropriate patterns for cost-sharing, Nigeria $(n=540)$

\begin{tabular}{|c|c|c|c|c|c|c|c|}
\hline $\mathrm{S} / \mathrm{N}$ & Patterns & $\begin{array}{c}\text { Farmers' } \\
\text { mean score }\end{array}$ & $\begin{array}{r}\text { Standard } \\
\text { deviation }\end{array}$ & $\begin{array}{c}\text { Extension } \\
\text { professional' } \\
\text { mean score }\end{array}$ & $\begin{array}{r}\text { Standard } \\
\text { deviation }\end{array}$ & $\begin{array}{c}\mathrm{t}- \\
\text { value }\end{array}$ & $\begin{array}{c}\text { Probability } \\
\text { level }\end{array}$ \\
\hline 1. & $\begin{array}{l}\text { Payment of cost of technology transfer through } \\
\text { community assembly every farming season }\end{array}$ & 2.62 & 1.24 & 2.49 & 1.11 & -1.29 & 0.19 \\
\hline 2. & $\begin{array}{l}\text { The extension organization should determine the } \\
\text { cost of technology transfer and charge a certain } \\
\text { proportion of the cost on the recipient }\end{array}$ & 2.69 & 1.11 & 2.93 & 1.03 & 2.65 & 0.01 \\
\hline 3. & $\begin{array}{l}\text { Payment of cost of technology transfer through } \\
\text { community assembly monthly }\end{array}$ & 2.19 & 1.13 & 2.08 & 1.01 & -1.34 & 0.18 \\
\hline 4. & $\begin{array}{l}\text { Beneficiaries should be paying a specified amount } \\
\text { to the extension organization every farming season } \\
\text { through their cooperative societies }\end{array}$ & 3.15 & 1.01 & 3.10 & 0.93 & -0.55 & 0.58 \\
\hline 5. & $\begin{array}{l}\text { Beneficiaries should be paying a specified amount to } \\
\text { the EA in-charge of their circle every farming season }\end{array}$ & 2.68 & 1.11 & 2.22 & 1.09 & -4.90 & 0.00 \\
\hline 6. & $\begin{array}{l}\text { Beneficiaries should be paying a specified amount } \\
\text { to the extension organization monthly irrespective } \\
\text { of technology disseminated }\end{array}$ & 2.18 & 1.13 & 1.84 & 0.92 & -3.93 & 0.00 \\
\hline 7. & $\begin{array}{l}\text { Beneficiaries should be paying a specified amount } \\
\text { monthly through their cooperative societies to the } \\
\text { extension organization. }\end{array}$ & 2.50 & 1.11 & 2.77 & 1.05 & 2.88 & 0.00 \\
\hline 8. & $\begin{array}{l}\text { Payment of cost of technology transfer through the } \\
\text { local council wards monthly }\end{array}$ & 1.84 & 1.05 & 1.73 & 0.91 & -1.32 & 0.19 \\
\hline \multirow[t]{2}{*}{9.} & $\begin{array}{l}\text { Payment of cost of technology transfer through the } \\
\text { local council wards every farming season }\end{array}$ & 2.10 & 1.14 & 1.94 & 0.99 & -1.78 & 0.08 \\
\hline & Overall mean pattern & 21.96 & 4.78 & 21.09 & 4.38 & -2.22 & 0.03 \\
\hline
\end{tabular}

mean scores for 'the extension organization should determine the cost of technology transfer and charge a certain proportion of the cost on the recipient' ( $\overline{\mathbf{X}}=2.93: 2.69)$ and 'beneficiaries should pay a specified amount monthly through their cooperative societies to the extension organization' $(\overline{\mathbf{x}}=2.77: 2.50)$. The overall difference between the respondents on the appropriate patterns of costsharing was significant $(t=-2.22)$, showing slightly higher overall mean score for farmers $(\overline{\mathbf{x}}=21.96)$ than for extension professionals $(\overline{\mathbf{X}}=21.09)$.

\section{DISCUSSION}

The most appropriate pattern identified by respondents for sharing the cost of agricultural technology transfer was for beneficiaries to pay a specified amount to the extension organization every farming season through their cooperative societies. It is interesting to find out that both farmers and extension professionals adopted this pattern as most appropriate for cost-sharing. Two important points are noted in this pattern. One, the respondents wanted the payment to be attached to the farming season when services are most relevant and preferably after the farming season when they must have realized income from sale of farm products (as observed during the FGD). Experience shows that it is helpful to determine the amount to be paid for a service only when its benefits can be assessed by users and extensionists (i.e., after harvesting and marketing the crop or livestock), at least until some confidence in the cost-sharing system has developed on both sides (Katz, 2002). This will make the service providers strive to deliver quality services to farmers. Farmers' compliance to payments will then mean that the services rendered to them are 
useful in increasing their farm income and livelihoods. This will be a good assessment index for almost all services of the extension professionals. Note that payments for almost all the choice patterns were recommended to be at the end of the farming season to make it convenient for farmers.

Secondly, respondents wanted the payment to be made through farmers' cooperative associations. The advantage of farmers pooling resources together through cooperative unions cannot be overemphasized. A previous related study shows that the age-long practice of one extension agent (EA) to farmer contacts, which though very effective is expensive and unsustainable as the sole means of reaching farmers with agricultural technology (Madukwe and Ozor, 2004). They further stated that new methods emphasize the taking of agricultural technology to farmers in organized groups (farmer associations). It is known that apart from gaining an economy of scale and policy advocacy through cooperative ventures, farmer associations also strengthen their bargaining power with traders, facilitate their savings and access to credit, reduce transaction costs for input supplies and output buyers, make agricultural extension service more client-driven, and allow farmers to interact more closely among themselves and share information willingly within the group (Conroy, 2003; Madukwe and Ozor, 2004). Farmer organizations have been known to serve as useful media for reaching a greater farmer audience in the most effective and efficient way in extension service delivery. Farmer groups and associations have the potentials to fund and pay for extension services (Ashby and Sperling, 1994; Bebbington et al., 1994; Apantaku et al., 2000). Cost-sharing therefore is more feasible when services can be provided to groups of farmers, because in this case the cost per individual user is less. Nonetheless, fears were raised on the probability of arbitrary charges by service providers hence the need for a well-structured cost-sharing programme with good policy back up, regulations, and proper monitoring in order to make the approach accomplishable.

Another pattern where the opinions of farmers and extension professionals concurred was for the extension organization to determine the cost of technology transfer and charge a certain proportion of the cost to the recipient. Here, farmers assume that under a good regulatory environment, standard rates backed up by policy will be charged depending on the category of service rendered and that they (farmers) will be fully involved in the determination of an appropriate charge. Previous studies showed that adequate regulations, legislations, and control by government in maintaining quality and standards in extension service delivery will encourage clienteles to participate in financing extension service (Ozor and Madukwe, 2005; Chukwuone et al., 2006). For transparency, accountability, and increased outcomes, charges should be based on the quality of service rendered and the impact such service is able to make on the overall livelihood of the clientele farmers as seen in increased production and income.

Also, payment of specified amounts monthly to extension organization by farmers through their cooperative societies was recommended as an appropriate pattern for cost-sharing by both respondents. The only difference between this pattern and the first is that respondents want to make the payments every month instead of annually, but still through their cooperative societies. This further stresses the need to use cooperative organizations as channels for effective delivery and funding of extension services. The five common sets of arguments for focusing extension support on groups rather than individuals are for efficiency, effectiveness for learning and action, equity, demand-orientation, and empowerment (Garforth, 2005).

On the other hand, a payment through the local council wards either monthly or every farming season was considered by the respondents as the most inappropriate pattern for cost-sharing. This may not be unconnected with the absolute lack of trust and confidence on politicians who most of the times are not democratically elected. It may equally suggest that attaching extension service delivery with politics will not yield a good result because of bias, corruption, and nepotism among others which bug the political environment. Politicians on the other hand, restrain from active support for extension because they often do not derive immediate payoff from extension programmes (Feder et al., 1999). The authors further noted that the aspects of agricultural extension services that tend to be inherently low cost and build reciprocal, mutually trusting relationships are those most likely to produce commitment, accountability, political support, fiscal sustainability, and the kinds of effective interaction that generate knowledge.

The more favourable outlook of farmers on the appropriate patterns for cost-sharing may be because they (farmers) are the people expected to make the payments (demand-driven) and therefore, stand a better chance to identify the most appropriate patterns suitable to them in the costsharing agenda more than the extension professionals. This confirms the fact that integrating farmers in decision-making processes of extension management can yield good results for the service. Participation draws marginalized people closer to the planning process, thereby enabling them to have more control over their own lives (Igbokwe and Enwere, 2001).

CONCLUSION \& RECOMMENDATIONS

The authors examined the appropriate patterns for effective cost-sharing of agricultural technology transfer in Nigeria. Results show that the most appropriate pattern of cost-sharing identified by 
respondents was for beneficiaries of services to pay a specified amount to the extension organization every farming season through their cooperative organizations. The respondents rejected payments through local government council wards noting that the pattern was most inappropriate. There was a significant difference in the opinions of farmers and extension professionals on the patterns for cost-sharing. Results show that farmers had more ideas on the best patterns of payments to adopt in order to achieve success in cost-sharing arrangement than extension professionals.

The authors recommend that agricultural technology transfer could be sustained if both government and clientele farmers participate in financing the programme. This could be achieved if the appropriate patterns already identified in this study are adopted and implemented by agricultural policy makers and extension administrators. However, efforts should be made by agricultural development agencies to encourage farmers to form farmer associations/cooperatives so as to make the delivery and funding of agricultural technology transfer easy. The clientele farmers must be involved in the decision-making and implementation processes of agricultural programmes if enduring successes are to be realized. The implication of involving farmers in programme development and implementation processes is that they tend to participate actively and bear responsibilities in such programmes.

\section{ACKNOWLEDGEMENT}

This research was supported with financial and technical assistance from African Technology Policy Studies Network, Nairobi (ATPS) and Commonwealth Scholarship Commission in the United Kingdom.

\section{REFERENCES}

Ameur C. (1994). Agricultural extension a step beyond the next step. World Bank Tech. Paper 247, Washington DC

Apantaku S.O., Sodiya C.I., Apantaku F.S. and Fakoya E.O. (2000). Alternative internal sources of funds for extension service in Ogun State, Nigeria. J. Sustain. Agric., 17 (1), 37-54

Ashby J.A. and Sperling L. (1994). Institutionalizing participatory-client-driven research and technology development in agriculture. AgREN Network Paper 49, London, Overseas Development Institute

Bale M. and Dale T. (1998). Public sector reform in New Zealand and its relevance to developing countries. World Bank Res. Obser., 13 (10), 103-121

Bebbington A., Merrill-Sands D. and Farrington J. (1994). Farmers and community organizations in agricultural research and extension: Functions, impacts and questions. AgREN Network Paper 47, London, ODI

Bryman A. (2004). Social Research Methods (2 ${ }^{\text {nd }}$ ed.), Oxford University Press, New York, p. 72

Chukwuone N., Agwu A. and Ozor N. (2006), Constraints and strategies toward effective cost-sharing of agricultural technology delivery in Nigeria. J. Int. Agric. Ext. Edu., Texas A\&M USA, 13 (1), 29-41
Conroy C. (2003). New directions for Nigeria's basic agricultural services. A Discussion Paper for Basic Agricultural Service (BAS), Natural Resources Institute, University of Greenwich, United Kingdom, p. 61

Feder G., Anthony W. and Willem Z. (1999). Agricultural Extension: Generic challenges and some ingredients for solutions. Policy Research Working Paper 2129. The World Bank, Washington, DC

Garforth C. (2005). Groups and organizations in extension. Comparative Extension Module - IDM005 (10). Int. Rural Dev. Department, University of Reading, UK

Head J.G. (1974). Public Goods and Public Welfare. Duke University Press, North Carolina

Igbokwe E.M. and Enwere N.J. (2001). Participatory Rural Appraisal in Development Research. New Generation Ventures Ltd., Enugu, Nigeria, p. 77

Igbokwe E.M. (2001). A survey of services provided by private veterinarians and agro-businesses in the poultry industry in Enugu State, Nigeria. Proc. 7th Annual National Conf. of the Agric. Ext. Soc. Nigeria, Ilorin, Nigeria, Agric. Ext. Soc. Nigeria, pp. 107-112

Katz E. (2002). Innovative Approaches to Financing Extension for Agriculture and Natural Resource Management. LBL, Swiss Center Agric. Ext, CH, pp. 135

Kelly L., Violeta D. and Insa T. (2012). The role of Bulgaria's extension service in supporting the Common Agricultural Policy (CAP). Outlook Agric., 41 (1), 21-25

Keynan G., Olin M. and Dinar A. (1997). Co-financed public extension in Nicaragua. World Bank Res. Obser., 12 (2), 225-247

Kuitenbrower J.B. (1981). The Dialectics of Class and State Formation and of Development Policy in Papua, New Guinea. Occasional Paper, No. 86, The Hague Institute of Social Studies

Madukwe M. and Ozor N. (2004). Emerging approaches and strategies in the delivery of agricultural extension service to farmers. J. Agric. Manag. Rural Dev., 1, 50-63

Meier G.M. (1995). Leading Issues in Economic Development. Oxford University Press, New York

National Council on Privatization (NCP) (2001). Privatization Handbook, ( $3^{\text {rd }}$ ed.), NCP Secretariat, Abuja pp. 114

Omagbemi O. (1998). Private Sector Involvement in Extension: The SPDC of Nigeria Limited example. In: Olowu T.A. (ed.), Proc. $4^{\text {th }}$ Annual National Conference of AESON, AESON, Ilorin, pp. 94-97

Ozor N., Agwu A., Chukwuone N., Madukwe M. and Garforth C. (2007). Cost-sharing of agricultural technology transfer in Nigeria: Perceptions of farmers and extension professionals. J. Agric. Edu. Ext., 13 (1), 23-37

Ozor N. and Madukwe M. (2005). Strategies for increased private sector participation in funding agricultural extension service in Nigeria: the professionals' reactions in Enugu State. J. Agric. Ext., 8, 7-15

Pigou A.C. (1932). The Economics of Welfare. (4th ed.), Macmillan, London

Umali D.L. and Schwartz L. (1994). Public and private agricultural extension-beyond traditional frontiers. World Bank Discussion Papers No. 236, The World Bank, Washington DC, pp. 85

Wilson M. (1991). Reducing the costs of public extension services: initiatives in Latin America. In: Rivera W.M. and Gustafson D.J. (eds.), Agricultural Extension Worldwide: Institutional Evolution and Forces for Change. Amsterdam: Elsevier 